\title{
STAGES OF MODERNISATION OF THE CONTENT OF PRIMARY SCHOOL EDUCATION: UKRAINIAN EXPERIENCE
}

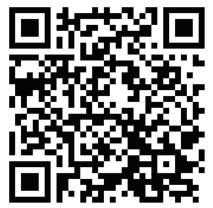

To cite this article:

\author{
Oleksandra Savchenko, Dr. Sc., Prof. \\ Chief Scientific Officer, Department of Primary Education, \\ Institute of Pedagogy, \\ National Academy of Educational Sciences of Ukraine, \\ Kyiv, Ukraine \\ savchenko.a.j@gmail.com \\ https://orcid.org/0000-0001-5040-0860
}

Savchenko, O. (2018). Stages of modernisation of the content of primary school education: Ukrainian experience. Education: Modern Discourses, 1, 130-141. https://doi.org/10.32405/2617-3107-2018-1-12

\begin{abstract}
The article highlights the Ukrainian experience of modernising the content of primary education under state independence of Ukraine. Based on the dynamics of the introduction of the State Standards for Primary Education and of a competence-based approach, the following four stages identified: the $1^{\text {st }}$ stage: a Law of Ukraine "On Education" (1996) was adopted, the theoretical and legal preconditions for the development of the national Ukrainian school and State Standard for the 11-year school developed; the $2^{\text {nd }}$ stage: the transition to a 12-year school started; its structure was defined, Concept of 12-year General Secondary Education was developed; the $3^{\text {rd }}$ stage: the working State Standard for the 4-year school was modernised; the $4^{\text {th }}$ stage: the new State Standard based on the provisions of the Law "On Education" (2017) and of the Concept of the New Ukrainian School adopted. The author reveals how an innovative algorithm for constructing a standard was applied, i.e., from obligatory outcomes of primary education in the state standards to the expected outcomes in typical educational programs; content, forms, methods are the means to achieve different types of educational outcomes.

Key words: primary education; modernising the content of education; the New Ukrainian School; State Standard; key competencies; educational outcomes.
\end{abstract}

\section{INTRODUCTION. PROBLEM STATEMENT}

The content of school education is a system-forming component of the educational process, an essential factor in its quality. Innovations regarding the content and duration of schooling clearly reflect the political and economic needs of a state and the values of society, the state of development of fundamental, psychological and pedagogical sciences, readiness for the proposed changes.

During the years of independence of Ukraine, the content of school education has been continuously changing in accordance with new laws, concepts, conditions that reflect the national needs for the development of schooling and attempts to take into ac- 
count foreign experience. Drafting new laws in the field of education, the definition of new methodological foundations for its development was carried out under conditions of political and economic instability, lack of forward-looking experiments, rapid pace of innovations, as a rule, without proper monitoring of their effectiveness.

Starting with the 90 -s of the 20-th century the process of modernisation of the content of primary education was continuously active despite of all the complexity. In particular, during this time there was a final transition to the 4-year term of primary schooling. The Law of Ukraine "On Education" (2017) states that primary school is the first level of the National Qualification Framework; it should ensure that pupils develop general skills and competences, lay the foundation for their further learning and personal development. During this time, three generations of state standards have been developed, ideas of a competence-based approach are getting more and more theoretically substantiated and practically implemented.

The purpose of the article: to highlight the genesis of the content of primary education during the years of state independence of Ukraine, define stages of its standardization, identify their connection with the introduction of a competence-based approach.

The study foresaw selection of information and complex processing of the following sources:

- Laws of Ukraine "On Education", normative provisions, methodology and theory of modernization of the content of school education; its analysis, comparison, interpretation;

- state standards and typical educational programs of primary education; substantiation of the stages of standardisation of primary education; definition of their essential features;

- analysis of experience of implementation of the state standards; definition of unresolved problems and directions of further modernisation of the content of primary education on the basis of a competence-based approach.

\section{MAIN RESULTS}

The conducted research made it possible to substantiate the four stages of modernisation of the content of primary education during the specified period. In this context, modernisation is understood as a purposeful significant improvement of education in accordance with changes in the legislative and methodological foundations of the Ukrainian school development, achievements of educational science and practice.

I-st stage (1992-1997) - the development of theoretical foundations and legislative requirements to modernisation of the content of education in the Ukrainian 11year school. In the early 1990-s, the most urgent need was for the de-politicisation of the content and introduction of the national character into school education. From this perspective cardinal transformations of the Soviet heritage started, i.e. the refusal or fundamental changes in the functional curricula, programs as well as their adaptation to the textbooks. Primarily it related languages, literature, geography and history curricula and textbooks.

In 1993-95 scholars of the Academy of Educational Sciences (AES) of Ukraine jointly with the Ministry of Education of Ukraine developed crosscutting concepts of the content of the state part of the curriculum for the 11-year school. Unfortunately, this innovative work was not completed due to the deep economic crisis. 
We consider the provisions of the National Program "Education" (Ukraine 21-st Century)" (1993) as a theoretical conclusion of this phase. For the first time in the Ukrainian educational space, strategic goals for reforming the content of national education were proclaimed in the section "Content of Education". The following are among them: the development of state standards for all levels of education; content differentiation and integration, provision of alternative opportunities for education in accordance with the individual needs and abilities of pupils; instruction the Ukrainian language in educational institutions of all types, the optimal combination of the humanities and the natural-mathematical component of education, the connection with national history, culture and traditions; creation of preconditions for development of youth's abilities, readiness for self-education, etc. (Dreval \& Zaika, 2006: p. 80-95).

Did these theoretical achievements contribute to the profound reformation of the content of school education? In our opinion, no. In practice, it was transformed selectively, often amateurishly, without taking into account its integrity, functions of each stage, the trends of education development in the foreign countries. The reasons for this are different: the lack of development of the methodology of the theory of school content, the politicisation of approaches, the un-readiness of the Ukrainian educational science and practice to the innovative concepts of school content, etc.

After the passing of the Law of Ukraine "On Education" (1996), the work had been started on the State Standards of General Secondary Education, which were considered as a universal means to ensure the quality of school education. This work was managed by O. Ya. Savchenko on the part of the Ministry of Education of Ukraine, S. U. Goncharenko - the AES of Ukraine, P. P. Tolochko - the National Academy of Sciences of Ukraine, O. I. Lyashenko - the Institute of Content and Methods of Education of the Ministry of Education of Ukraine.

In 1996, the College of the Ministry of Education approved the Concept of the State Standard of General Secondary Education. It defined the essence of the standard, the basic curriculum, where the educational branches were indicated, the hours for their instruction during the years of study, the form of control over the observance of the requirements for the acquisition of the minimum level at each educational level, etc. The draft Baseline Curriculum comprised 8 educational areas: Ukrainian as a state language, literature, artistic culture, social science, natural science, mathematics, physical culture and health, technology.

In 1997 draft State Standards for 11-year school for each educational area was published.

In the primary school, school content modernisation was carried out as part of modernisation of a holistic content. In this period new subjects "Ukrainian studies" and "Ethnography" were introduced, in which the ideas of the revival of the Ukrainian national culture were realized in a systemic way.

Therefore, in a very short period, under the absence of additional funding and sharp discussions, which were often of a political nature, the developers managed to create fundamentally new documents for the Ukrainian education. However, in our opinion, the standard developers did not manage to minimize the volume of the educational areas content, poorly implemented the principle of continuity. They not properly implemented developmental and educational potential of content for the personal development of schoolchildren. 
II-nd stage (1998 - 2010) - beginning of transition to the 12-year school. Adoption of the Law of Ukraine "On General Secondary Education" (1999) led to a rethinking by the educational science and practice of the goal and objectives of general secondary education as a social institution as an integral system and, at the same time, as component of continuing education that should meet the challenges of the 21-st century.

It is determined that the goal of school education is the development of a personality - "intellectual, social and physical", and the basis of this goal is the multicomponent content of education, which should include "systematic knowledge about nature, man, society, culture and production, as well as means of cognitive and practical activities". The selection and mastering of the content by pupils "is based on the universal values and principles of science, multicultural character, the secular nature of education, consistency, integrity, unity of education and upbringing on the basis of humanism, democracy, civic consciousness, mutual respect between nations and peoples in the interests of a man, family, society, state" (Dreval \& Zaika, 2006: p. 70-98). The methodological foundations of the systematic development of Ukrainian education were reflected in the National Doctrine of Education Development, which was approved by the $2^{\text {nd }}$ AllUkrainian Congress of Educators in 2002. This document clearly defines the goals and duration of school education, the directions of content modernisation.

For the first time in the national educational legislation, requirements were set for the goals and content of instruction in the 12-year school. Its new structure comprised: 4-years primary school, 5-years law secondary school, 3-years high secondary school (the latter was proclaimed as a profession-oriented school (Dreval \& Zaika, 2006: p. 77).

The transition to the new 12-year structure required a thorough definition of the methodology of this process, of the priority tasks of each stage of school education, and a clear elaboration of mechanisms of continuity between them in accordance with the age-specific characteristics of pupils. This was reflected in the Concept of General Secondary Education (12-year school), developed by scholars of the AES of Ukraine (Dreval \& Zaika, 2006: p. 14-34).

The universal and national values, centring on the topical and future interests of a child was defined as a methodological basis of the content of school education. It was emphasized that the content of the 12-year school should be modernized in such a way that the school graduates could quickly adapt in their independent lives, purposefully use their potential both for the choice of the profession, and in personal life being aware of the interests of the society and the state. These approaches were specified in the Basic Curriculum of the State Standard, which standardised the main parameters of the organisation of the educational process: its duration, the distribution of time over the years of instruction, the educational areas, and the invariant and variable components of the school education.

In particular, in the 4-year primary school, mastering the basic general skills and abilities of pupils, preserving the priority of educational and general development goals remained a priority. In the structure of the primary school it was necessary to take into account the existing two cycles: children $6-7$ years of age ( $1-2$ grades) and $8-10$ years of age ( $3-4$ grades) (Noteworthy, this approach is now reflected in the new State Standard). Accordingly, one should take into account the peculiarities of the physical, mental, intellectual development of children in the organizational, content and methodological provision of the educational process. For primary education continuity with pre-school education was still unresolved, equal start-up opportunities for 
pre-school children were not created. The competency-based approach in constructing content was not applied at that stage.

The approval of the State Standard of Primary Education (2001) started a new stage in the development of the Ukrainian primary school (Savchenko, 1999: p. 12-15). However, this process was taking place at time when there were no clear requirements regarding the continuity and prospect of this level of education.

For the first time in the history of the national education not typical (as it was for decades), but variable programs were developed, which resulted in new textbooks for 4-year primary school.

According to the results of approbation of new programmes and textbooks, the State Standard of Primary Education approved by the Cabinet of Ministers of Ukraine in 2001 was transformed in 2005. In comparison with the 4-year primary school, which was valid until 2001, this document identified a performance component of the content of education, strengthened integration at the level of content area, enriched its practical orientation, etc. (Savchenko, 1999: p. 12-15).

The content of primary education was modernised in a way to improve the implementation of a child development priorities, preserve of children's health, strengthen Ukrainian-centric nature of instruction, humanisation, differentiation, and increase the proportion of practical and creative tasks; the work of pupils with a computer as a means of educational activity. With the purpose of social development of junior schoolchildren, the instruction of the ecological worldview was introduced in a format of an integrated course "Man and the World". Its content could be realized by means of various programs ("Environment at a glance", "Natural science", "Man and the world", "Environment"); Variable programs on labour education, fine arts, music, foundations of health and physical culture were approved. Since 2002 instruction of foreign languages in all schools starting from the $2^{\text {nd }}$ grade started.

Work on the State Standard was carried out by scholars of the Institute of Pedagogy and the Institute for Problems of Education of AES of Ukraine (O. Savchenko, M. Vashulenko, T. Baibara, N. Bibik, I. Gudzik, L. Kochina, N. Lystopad, N. Koval, O. Khoroshkovska, V. Martynenko, V. Tymenko, L. Masol, M. Zubaliy).

Thus, the approval of the Concept of General Secondary Education (12-year school), which outlines the theoretical foundations for the modernization of the content of the 12-year school, the approval of the first State Standard of the 4-year primary education, the publication of variable programs are the outcomes of the II stage of the content development.

III-d stage (2011 - 2013) - the working State Standard was modernised in order to implement a competence-based approach into selection of the content and definition of the results of primary education.

In 2010, the Concept of the Second Generation of the State Standard for Primary School was developed (Savchenko, 2010: p. 1-5), which emphasized that "quality education for all" had to be at the same time "quality education for everyone". Primary school should envisage the acquisition of competencies by pupils - individual experience in applying knowledge, skills, and identifying a value relation to them.

Positive changes in structuring terminology and introduction of a competencebased approach into normative documents were prepared by the works of the Ukrainian comparative education scholars. The comparative educators studied the trends of modernisation of the content of school education in the developed countries (A. Sbruieva, 
O. Lokshyna, O. Ovcharuk, etc.) and offered productive recommendations for the modernisation of school education content in the Ukrainian realities (Derzhavnyi standart; Ovcharuk (ed.), 2004).

It is positive that besides subject competences key competencies - the ability to learn, informational and communicative competence, general culture competence, health saving competence, civic and social competence - were introduced ibto the State Standard for the first time in the modern history of educational standards development. The outcomes of mastering the educational material were defined in "state requirements to the level of general education attainment of pupils" (a pupil knows, understands, applies, and reveals his/her attitude) (Derzhavnyi standart, 2011: p. 5-6).

The content and structure of the working State Standard (2011) underwent significant changes: as separate two educational areas: natural science and social science were introduced; technology was represented only by the content line - familiarization of pupils with ICT - which, starting from the $2^{\text {nd }}$ grade was supposed to study with propaedeutic aim in the course "Steps to computer science". From our point of view, these changes were not scientifically substantiated, i.e., many complicated topics for the younger schoolchildren and sometimes-erroneous provisions in the new programs and textbooks (as shown by their use) were introduced. Therefore, this stage of the modernisation of the content of primary education has contradictory results.

It is positive that the State Standard extended the limits of the use of the competence-based approach, i.e., the competence requirements for the learning outcomes in the content of certain educational areas were more clearly reflected, the relationship between key and substantive competencies was emphasized. At the same time, the content of primary education was not systematically modernised on the basis of a competence-based approach, the modernisation was limited to selective local changes, the results of mastering the educational material of educational areas by pupils were defined without taking into account their intrinsic and inter-subject connection; key competencies were listed, the State Standard and the programs did not contain requirements for their mastering.

IV-th stage (2014 - 2018) - development of the State Standard of the Content of Primary Education on new legislative, methodological, didactic and methods bases. Over the years, a large volume of new education development documents have been developed - the Law of Ukraine "On Education" (Savchenko, Bibik, Martynenko ta in., 2016: p. 1-4), the Concept "New Ukrainian School" (2016), the State Standard of General Secondary Education (2016), the State Standard of Primary Education (Zakon Ukrainy "Pro osvitu", 2017), two typical educational programs for primary school (Savchenko, 2012: p. 1-6).

The development of the new State Standard was preceded by the improvement of the curricula of the working State Standard (2011) started with a broad public discussion (2015 - 2016) in the media. The purpose of the changes was to unload the instruction contents and requirements to the learning outcomes, improve the logical sequence of studying its seperate sections, extracting secondary material, etc. (Navchalni prohramy dlia zahalnoosvitnikh navchalnykh zakladiv iz navchanniam ukrainskoiu movoiu 1-4 klasy, 2011; Navchalni prohramy dlia zahalnoosvitnikh navchalnykh zakladiv. 1-4 klasy (zi zminamy), 2015).

The theoretical foundations for the development of a new content stated in the Rationale of Standards of the General Secondary Education (O. I. Lyashenko carried out 
scientific guidance on the part of the National Academy of Sciences (NAES) of Ukraine). Therefore, the development of the State Standard of Primary Education was the first step in the process of the development of General Secondary Education Standard. It was aimed at promoting the integrity and continuity of the modernisation of the content of education of the Ukrainian school on a universal methodological and theoretical basis, at application of the universal characteristics of key competencies.

The new State Standard for Primary Education was created as an innovative product with the participation of a wide range of stakeholders. A group of scholars of the NAES of Ukraine took an active part in its development. The experience of foreign countries where reforms of the content of primary education on the basis of standardization and competence-based approach have taken/are taking place has been taken into account (Poland, Scotland, Northern Ireland, etc.) (Lokshyna, 2010: p. 17-181; Ovcharuk (ed.), 2004; Typovi osvitni prohramy dlia zakladiv zahalnoi serednoi osvity: 1-2 klasy, 2018).

The principle of child-centeredness in all its dimensions and activity approach, which is the basis of the competence-based approach are defined as theoretical principles of constructing the content of primary education. It was necessary to take into account not only the actual needs of a modern child, but also lay the potential for his/her long-term development, readiness to continue education in the basic school. We believe that in the process of modernising the content (and further, in teaching methods), it is necessary to take into account not only aspects/issues that children are interested in, but also professionally and responsibly to ensure their further progress, which involves obtaining the required and expected educational outcomes, because real achievements can be used to assess the quality of changes in the primary education.

The greatest innovation in this stage of standardization of school content is the phenomenon of a new understanding of the outcomes of education. Now the design of the content of primary education is fundamentally different. International and national experience has confirmed that the most productive is the approach, when instrumental knowledge being the basis for assimilation of ways of action is dominated during instruction. If educational outcomes become a benchmark in determining the content of primary education, then the competence-based approach, which was used in the previous State Standard, becomes a means to achieve another quality of education. Under these conditions, teachers must objectively distinguish between the process and the learning outcomes, and pupils gradually learn to distinguish knowledge about the facts, phenomena and knowledge about the means of action.

The normative basis here are provisions of the Law "On Education" on educational outcomes. In particular:

- learning outcomes that are broader than competencies; they can be identified, planed, evaluated and measured; the person is able to demonstrate them after the completion of the educational programme (Zakon Ukrainy "Pro Osvitu", 2017: art. 1, parg. 22);

- key competencies program (Zakon Ukrainy "Pro Osvitu", 2017: parg. 11, 15), which are recommended for all levels (fluency in the state language, ability to communicate by mother tongue (in case it differs from the state language) and foreign languages; mathematical competence, competence in the field of natural sciences, technology; innovation, environmental competence, informational - communication, civil and social competencies, cultural competence, lifelong learning, entrepreneurship and financial literacy; 
- common for all competences skills: reading with understanding, ability to express one's opinion orally and in writing; critical and systemic thinking; creativity, imitativeness, ability to constructively manage emotions, ability to co-operate with other, etc.

The introduction of a new terminology on educational outcomes and its further implementation in typical programs and textbooks reflects a change in the goals of education, which should gradually become productive. This led to the need to rethink the selection of content, ensuring its proximity to the children's vital needs, harmonizing the complexity and volume of educational material with predictable outcomes.

In the State Standard, the requirements for the compulsory outcomes of primary education and competencies of pupils are determined by the following educational areas: linguistic and literary (Ukrainian language and literature, languages and literature of the national minorities, foreign language teaching and learning); mathematical; natural science; technological; ITC; social and health saving; civil and historical; artistic; physical education. Consequently, in comparison with the previous Standard, the new document presents a different set of educational areas: their number ( 9 areas) increased, some titles were changed.

According to the new State Standard, two typical educational programmes are developed that meet its requirements, but present the expected outcomes, content and volume of the integrated courses differently (Savchenko, 2012: p. 1-6).

We will comment on the didactic potential of the Typical Educational Program developed by the scholars of the NAES of Ukraine (Savchenko, 2012: p. 190-237). It is based on the principles of child-centeredness and environmental compatibility; coordination of the objectives of the subject (course) with the expected outcomes and content; practical orientation of the expected outcomes; accessibility and scientific content; continuity and perspective content for the development of a child; interconnected formation of key and subject competencies in each educational area; opportunities to implement the content of education through subjects or integrated courses; possibilities to adapt the content of the program to the individual peculiarities of children (intellectual, physical, cognitive).

Taking into account the integrated nature of each competence, the program recommends systematic use of intrinsic and interpersonal relationships that promote the integrity of the outcomes of primary education and the transfer of skills in new situations, and is a prerequisite for the formation of basic (crosscutting) abilities.

In the process of developing a typical educational programme the scholars have defined the following aspects of research: how to prevent the possibility of overloading in a new primary school; how to define the "core of content" for integrated courses, what number of educational areas and what is appropriate to integrate, how to predict in each of the areas the interconnection of key and subject competencies, because all competencies are important, but each educational area has its own priorities for their formation. The new document of the European Commission (Brussels) on the modernised European Reference Framework of Key Competencies for Lifelong Learning (January 2018) confirmed the effectiveness of the application of a competence-based approach in the education of different countries. It is determined that its correct implementation allows one to expect the development of critical thinking of young Europeans, the ability to solve problems, teamwork skills, communication and negotiation as well as analytical and creative abilities, and the perception of values between cultures (O. Lokshyna and others).

The analysis of the third generation of State Standard development process allows 
us to identify the following features: at this stage, the development of a new Law "On Education", the methodology of reforming secondary education and the practical reflection of the requirements of these documents in State Standard projects and typical educational programs for primary school took place almost simultaneously. The rapid pace of work has resulted, from our point of view, in inadequate consistency with the basic Law "On Education" regarding the reflection of the whole range of key competencies and basic skills in the State Standard and typical educational programmes. The implementation of a competence-based approach into the development of the State Standard, and then into the typical educational programmes was carried out fundamentally in a new way: from the obligatory and expected outcomes to the definition of the content of the education they corresponded to. Therefore, this generation of the State Standard can be considered as a competency oriented one.

The impact of the new Standard and programs on the quality of primary education in general and on the individual achievements of pupils can be defined by the results of monitoring of the new instruction and methodological support and relevant changes in the training of teachers, the methodology of which should be developed and assessed by experts.

\section{CONCLUSIONS}

Modernisation of the content of primary education in our country is carried out continuously in the context of transformations of general secondary education, which is caused by many factors, i.e. political, economic, pedagogical factors, society needs, children and parents' demands, quality education provisions, aspirations of the country to enter the European educational space). The main direction of these changes is accessible and high-quality education for all children, a humane, democratic, personally oriented school.

Standartisation of the content of education is recognised as an indispensable tool for achieving quality education, and a competence-based approach - as a tool for its personal focus and effectiveness, The Ukrainian education, as compared to the EU countries, began to develop these ideas much later. This is primarily due to the long, complicated and contradictory process of determining the methodological foundations for the development of the Ukrainian national school, the need to fundamentally change the legislation inherited from the USSR in the early 1990's and to create a new dimension for the functioning of the Ukrainian school under conditions of state independence.

Analysis of many sources and practice of schooling, direct personal involvement in the process of developing and implementing new content allows us to determine that during the period of independence large-scale changes in the area of school education have been taken place. In the process of modernising the content of primary education, four stages are identified respectively the progress of the implementation of the ideas of standardisation and competences in the legislation of education, the methodology of selection the content, its normative provision: I stage - 1992-97; II stage - 1998-2010; III stage - 2011-2013; IV stage - 2014-2018.

I-st stage (1992-1997) - the development of theoretical foundations and legislative requirements to modernisation of the content of education of the Ukrainian school. In the National Program "Education" ("Ukraine 21-st Century)", 1993), for the first time the development of state standards for all levels of education was proclaimed. In the Law "On Education" (1996) the notion "state standard" was defined as a universal means of 
ensuring the quality of education. After adopting the Concept of the State Standard of General Secondary Education by the Ministry of Education and Science of Ukraine the first standards for all levels of the 11-year school were developed.

II-nd stage (1998-2010) - the beginning of transition to the 12-year school, the definition of its goals, tasks, the new structure $(4+5+3)$, development of the requirements to the content of education at each level. This was reflected in the provisions of the Law "On General Secondary Education" (1999), the Concept of General Secondary Education (12-year school) (2000), the National Doctrine of Education Development (2002), theoretical developments on didactics. Based on these principles, the State Standard for a 4-year School was developed as a part of a 12-year school, in which the performance component was modernised. The competence-based approach has been proven, but not used, although for the first time a distinction was made between content and levels of pupils' achievements.

The progress of the 12-year school was artificially interrupted by the Verkhovna Rada of Ukraine at the initiative of the Ministry of Education and Science of Ukraine for political reasons in 2010. The assessment of the results of the functioning of the primary school under the new Standard were not conducted.

III- $d$ stage (2011-2013) - the working Standard for a 4-year School was improved; the competency-based approach has been used more fully in defining the content of instruction and the learning outcomes (state requirements to pupils' learning attainments are indicated). However, the changes made were partial and scientifically groundless; the traditional approach to constructing the standard was used: from the content to the outcome, which emphasized the attention of the teachers to the knowledge component, rather than the pupil's development achievements.

IV-th stage (2014-2018) - State Standard based on the provisions of the new Law "On Education" (2017), the Concept of "New Ukrainian School", and Fundamentals of State Standards for General Secondary Education is developed. In addition to national sources, the ideas of constructing the standards of primary education in different countries have been used for the definition of educational areas, content lines, general and compulsory outcomes. The number of educational areas has increased, the titles of some areas have been changed; an innovative algorithm for presentation of the outcomes of primary education applied.

The study of the State Standard educational programmes (2018) shows that they have actually applied the ideas of a competence-based approach, there is a certain relationship between key and subject competencies, the primary outcomes, and the content, form of organization - the means of achieving them.

The process of implementation of the State Standard (2018) has just started. As we hope, it is productive and promising in achieving the predicted quality of primary education, however, we are to think about preventing possible risks and preparing for fighting new challenges taking into account the experience of countries where such transformations are taking/have taken place. In particular, it was not achieved the continuity and promising outlook of the Standard. This will result its multiple correction from the point of view of the achievements gained by pupils in pre-school education as well as the needs of the lower secondary school. We consider to be insufficient reflection of the value aspect of the competence-based approach in the outcomes of the State Standard and the educational programmes. It is necessary to do it in the new methods support materials. 
It will be possible to understand the balance of the expected outcomes with the instruction time offered in the Standard and typical educational programs only in the implementation process. Outside the discussion, there remains a problem of the criterial assessment of competences acquired by junior pupils; this becomes particularly difficult in relation to the key competencies that are the base of the construction of the Standard.

Forward-looking experiments require a scientific substantiation of the optimal types and scope of integration of the content of instruction in the context of the relationship between the formation of subject and key competencies and crosscutting skills.

Under conditions of the variability of educational programmes, it is necessary to propose to the educational community and parents a guidance on ensuring the quality under different conditions of primary schooling with pupils with different cognitive and physical abilities.

The development of a new standard and typical programs should be proactive and take into account the results of monitoring the quality of the current Standard.

Thus, during the years of state independence, the modernisation of the content of primary education was carried out continuously, at different pace. The ideas of a competence-based approach were used differently in the process of development of three generations of State Standards: from the list of competencies to their presentation in content lines in the form of structural elements of the general mandatory outcomes, and in the typical programmes in the format of the expected outcomes. In the course of long-term progress, the competence-based approach becomes an instrumental one in establishing the connection between educational outcomes of primary education and the selection of relevant content, the use of different forms and methods of instruction, and ways of assessing the educational achievements of pupils.

\section{REFERENCES}

Berezivska, L. D. (2008). Reformuvannia shkilnoi osvity v Ukraini u XX stolitti : monohrafiia [Reforming school education in Ukraine in the twentieth century: monograph]. Kyiv: Bohdanova A.M. (in Ukrainian)

Bibik, N. M. (2010). Kompetentnist i kompetentsii v rezultatakh pochatkovoi osvity [Competence and competencies in the results of primary education]. Pochatkova shkola, 9, 2-5.

Derzhavnyi standart (2018) [State standard]. Retrieved from https://www.kmu.gov.ua/ua/ npas/pro-zatverdzhennya-derzhavnogo-standartu-pochatkovoyi-osviti

Derzhavnyi standart pochatkovoi zahalnoi osvity (2011). [State standard of primary general education]. Pochatkova osvita, 18, 5-6.

Dreval, H. F. \& Zaika, A. M. (ed.) (2006). Knyha kerivnyka navchalno-vykhovnoho zakladu: dovidkovo-metodychne vydannia [Book of the head of the educational institution: a reference and methodical publication]. Kharkiv: TORSINH plius. (in Ukrainian)

Kremen, V. H. (ed.) (2010). Bila knyha natsionalnoi osvity Ukrainy [White Book of National Education of Ukraine]. Kyiv: Inform. Systemy. (in Ukrainian)

Lokshyna, O. I. (2009). Zmist shkilnoi osvity u krainakh Yevropeiskoho Soiuzu [Content of school education in the countries EU]. Kyiv: Bohdanova A.M. (in Ukrainian)

Lokshyna, O. I. (2015). Transformatsiini protsesy v pochatkovii osviti krain Yevrosoiuzu: perspektyvni idei dlia Ukrainy [Transformational processes in primary education of EU coun- 
tries: perspective ideas for Ukraine]. Pochatkova shkola, 5, 37-39.

Navchalni prohramy dlia zahalnoosvitnikh navchalnykh zakladiv iz navchanniam ukrainskoiu movoiu 1 - 4 klasy (2011) [Educational programs for general educational institutions with Ukrainian language education 1 to 4 classes]. Kyiv: Osvita. (in Ukrainian)

Navchalni prohramy dlia zahalnoosvitnikh navchalnykh zakladiv. 1-4 klasy (zi zminamy) (2015) [Curricula for general education institutions. Grades 1-4 (with changes)]. Ternopil: Mandrivets. (in Ukrainian)

Ovcharuk, O. V. (ed.) (2004). Kompetentnisnyi pidkhid u suchasnii osviti: svitovyi dosvid ta ukrainski perspektyvy [Competency approach in modern education: world experience and Ukrainian perspectives]. Kyiv: K.I.S. (in Ukrainian)

Rozvantazhennia ta onovlennia prohram pochatkovoi shkoly (2016) [Unloading and updating of primary school programs]. Pochatkova shkola, 9-10, 1-23.

Savchenko, O. (2006). Pidsumky pershoho etapu funktsionuvannia pochatkovoi shkoly u skladi 12-richnoi [The results of the first stage of the primary school functioning as part of the 12-year-school]. Pochatkova shkola, 1, 4-8.

Savchenko, O. (2012). Kompetentnisna spriamovanist novykh navchalnykh prohram dlia pochatkovoi shkoly [Competency orientation of new curricula for primary school]. Pochatkova shkola, 8, 1-6.

Savchenko, O. Ya, Bibik, N. M. \& Martynenko, V. O. (2016). Kontseptsiia pochatkovoi osvity [The Concept of Primary Education]. Pochatkova shkola, 6, 1-4.

Savchenko, O. Ya. (2014). Uprovadzhennia kompetentnisnoho pidkhodu v pochatkovu osvitu: zdobutky i nerozviazani problem [Implementation of a competency approach to primary education: achievements and unresolved problems]. Ridna shkola, 4-5, 12-16.

Savchenko, O. Ya. (2018). Pochatkova osvita v konteksti idei Novoi ukrainskoi shkoly [Primary education in the context of the ideas of the New Ukrainian School]. Ridna shkola, 1-2, 2-6.

Savchenko, O. Ya. Kontseptsiia rozroblennia novoi redaktsii Derzhavnoho standartu pochatkovoi zahalnoi osvity [Concept of development of a new edition of the State standard of primary general education]. Pochatkova shkola, 4, 1-5.

Savchenko, Oleksandra (1997). Problemy rozrobky derzhavnykh standartiv zahalnoi serednoi osvity v Ukraini [Problems of development of state standards of general secondary education in Ukraine]. Pochatkova shkola, 7, 2-5.

Savchenko, Oleksandra (1999). Zakon "Pro zahalnu seredniu osvitu" - novi umovy yii stabilnoho rozvytku [Law "On general secondary education" - new conditions for its stable development]. Pochatkova shkola, 11, 12-15.

Typovi osvitni prohramy dlia zakladiv zahalnoi serednoi osvity: 1-2 klasy (2018) [Typical educational programs for institutions of general secondary education: $1-2$ forms]. Kyiv: TD "Osvita-Tsentr+". (in Ukrainian)

Yarova, O. B. (2018). Tendentsii rozvytku pochatkovoi osvity v krainakh Yevropeiskoho Soiuzu (kinets XX - pochatok XXI st.) [Trends in the development of primary education in the countries of the European Union (end of the XX - beginning of the XXI century)]. Kyiv: Pedahohichna dumka. (in Ukrainian)

Zakon Ukrainy "Pro osvitu” (2017) [Law of Ukraine “On Education”]. Retrieved from http:// zakon2.raba.gov.ua/laws/snow/2145-19 